\title{
A REVIEW ON PHYTOCHEMICAL AND PHARMACOLOGICAL POTENTIAL OF WATERCRESS PLANT
}

\author{
SACHIN CHAUDHARY*, HAZAR HISHAM, DOHA MOHAMED \\ Department of Medicinal Chemistry, College of Pharmacy, University of Sharjah, Sharjah-27272, United Arab Emirates. \\ Email: schaudhary@sharjah.ac.ae
}

Received: 31 August 2018, Revised and Accepted: 20 October 2018

\begin{abstract}
Nasturtium officinale (family: Brassicaceae) that is commonly known as watercress is a fast-growing aquatic or semi-aquatic perennial plant native to Europe, Central Asia. It is a highly significant food supplement, extensively consumed with salad, juices, or other dishes as an ingredient, flavor, or garnish. The leaves are traditionally used as stomachic, depurative, diuretic, expectorant, hypoglycemic, odontalgic, and stimulant. Meanwhile, it has been used to treat jaundice, asthma, bronchitis, scurvy, tuberculosis, urinary tract infection, and calculi. N. officinale is rich in glucosinolates, carotenoids, polyphenols, as well as Vitamin C, Vitamin A, and $\alpha$-tocopherol. It is the main source of iron, calcium, iodine, and folic acid.
\end{abstract}

Keywords: Asthma, Carotenoids, Folic acid, Hypoglycemic, Tuberculosis, Vitamin.

(C) 2019 The Authors. Published by Innovare Academic Sciences Pvt Ltd. This is an open access article under the CC BY license (http://creativecommons. org/licenses/by/4. 0/) DOI: http://dx.doi.org/10.22159/ajpcr.2018.v11i12.29422

\section{INTRODUCTION}

Herbs and traditional medicines are the most reasonable source of treatment in the human health-care system that has been used for the treatment of multiple diseases since classical times [1]. The local people have enduring history of traditional plant usage for medicinal purposes $[2,3]$. The conclusive therapy effects are due to the presence of bioactive phytochemical constituents such as alkaloids, bitters, flavonoids, bioflavonoids, glycosides, mucilage, saponins, tannins, phenols, phenolic acids, coumarins, terpenoids, essential oils, lectins, and polypeptides $[4,5]$. According to the WHO reports, in many developing countries, $80 \%$ of people trust on traditional practitioners and their armamentarium of medicinal plants to meet health-care needs $[6,7]$. The term "traditional" does not signify conventional or allopathic; rather, it represents historical/cultural/folk system of medicine that would be assumed as "alternative" in western context $[8,9]$. Nowadays, medicinal plants are resources of novel drugs and many modernized medicines are originated from plants [10-12]. Nearly 12,000 compounds have been isolated from plants until now that accommodate biological efficacy [13]. About $25 \%$ of the medicinal agents prescribed around the globe originate from plants, 121 such active compounds being in the current use. Irrespective of 252 drugs considered as basic and essential by the WHO, 11\% are originate from plants and various synthetic drugs obtained from natural precursors [14-16]. The current review is to provide complete latest information of the phytochemical properties of Nasturtium officinale, one of the plants, that is, being explored for multiple health benefits.

\section{PLANT DESCRIPTION}

$N$. officinale is a perennial dicotyledonous herb usually found in close proximity to water. As a member of the Brassicaceae family, it is related to several popular food and spice crops such as broccoli, cabbage, kale, radish, and mustard, as well as the model plant. In particular, watercress has been used as a medicinal and food crop for over many decades [17-22]. Morphologically (Fig. 1), N. officinale has small hairs, unbranched unicellular, and smooth sharp apex [23-25]. The plant is perennial, growing to $0.5-1$ meter at a fast rate. The leaves are 4-12 cm long, compound with many wavy edged, oval- or lance-shaped leaflets growing from central stalk $[26,27]$. The stem is $10-60 \mathrm{~cm}$ with thin and fibrous roots at the bottom. At the top of stems and short stalks, its flowers, white in color, are 3-5 $\mathrm{mm}$ long and have four petals [28,29].
The fruits are 10-25 $\mathrm{mm}$ long and $2 \mathrm{~mm}$ wide and found on stalks that are 8-12 mm long. The fruits are thin, slightly curved cylinders and contain four rows of small, round seeds [30,31]. The plant begins to flower from May to October and the seeds ripen from July to October. The flowers are hermaphrodite and are pollinated by bees, flies, etc. According to the concentration of phosphorus present in water, the roots are divided into two types. When the phosphorus concentration is high, the roots are adventurous; however, when the concentration is low, the roots are mainly taproots. It has special spicy taste with food just like strong pepper [21,26,28,30,32-34].

\section{TAXONOMICAL CLASSIFICATION}

The taxonomy of $N$. officinale is in the kingdom (Plantae), order (Brassicales), family (Brassicaceae), genus (Nasturtium), division (Magnoliophyta), class (Magnoliopsida), subclass (Dilleniidae), order (Capparales), and species ( $N$. officinale). The genus Nasturtium comprises from five species such as $N$. officinale, Nasturtium microphyllum, Nasturtium gambellii, Nasturtium africanum, and Nasturtium floridanum [35].

\section{NOMENCLATURE}

The land of origin of $N$. officinale includes Western Asia, India, Europe, and Africa, but now, it is almost present worldwide. It is considered as being introduced to North and South America, Southern Africa, Australia, and New Zealand. The plant has three synonyms, namely Rorippa nasturtiumaquaticum (L.), Nasturtium nasturtium-aquaticum (L.), and Sisymbrium nasturtium-aquaticum L. The vernacular name is watercress [36-39].

\section{PHYTOCHEMICALS CONSTITUENTS}

$N$. officinale is enriched with glucosinolates, carotenoids, polyphenols, as well as Vitamin C, Vitamin A, and $\alpha$-tocopherol [40-42]. It is a main source of iron, calcium, iodine, and folic acid [43-46]. It provides a reservoir of tannins, flavonoids, terpenoids, and many other glycosides. It is a rich source of essential vitamins and minerals such as lutein and zeaxanthin [47-52].

\section{ANTIOXIDANT ACTIVITY}

Zeb [53] reported antioxidant potential, pigments, and phenolic composition of watercress leaves and roots. The study reported that 

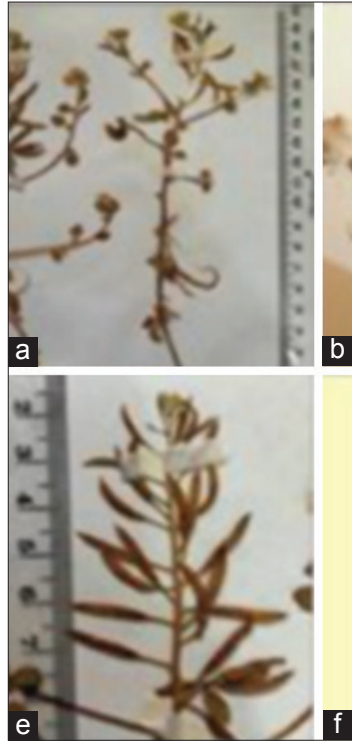
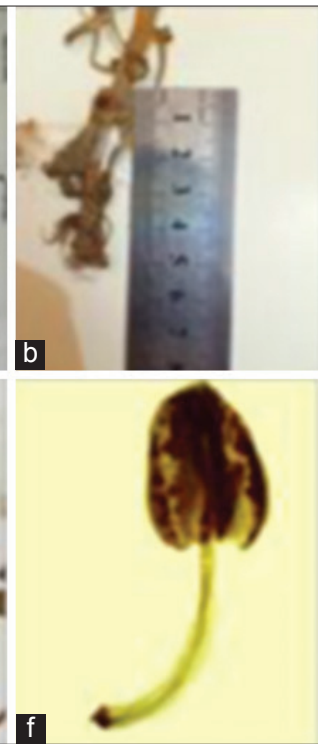
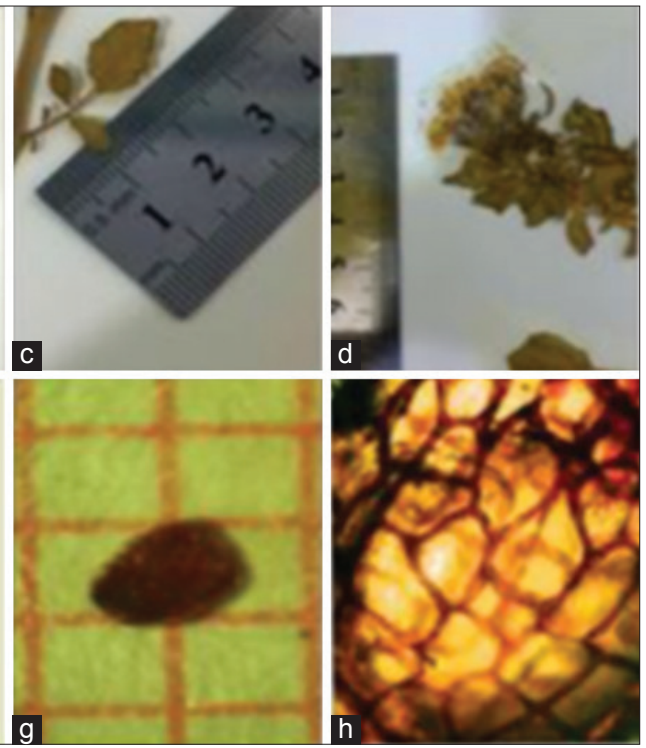

Fig. 1: Morphological characters in Nasturtium officinale. (a) Whole plant; (b) Roots; (c) Leaf; (d) Inflorescence system; (e) Fruits; (f) Stamen; (g) Seeds; (h) Ornamentation in seed surface

pigment chlorophyll was found in predominant concentration and total phenolic (TP) compounds were dominant in methanolic extract compared with aqueous extract. Total 14 phenolic compounds were determined in the leaves, where coumaric acid and its derivatives, caftaric acid and quercetin derivatives existed in superior amount. In roots, 20 compounds were identified, of which the above-mentioned compounds were found in higher concentration. The radical scavenging activity (RSA) of root, stem, and leaves of watercress methanolic extract were $70.0,78.0$, and $81.6 \%$. There was a significant $(P<0.05)$ increase in percentage RSA in the methanolic extract with the order of root $=$ stem < leaves. Mazandarani et al. [54] reported the relationship between secondary metabolites content and antioxidant activity in aerial parts of $N$. officinale R. Br., at various altitudes and periods of growth in northern Iran. TP and total flavonoids (TFs) contents in aerial parts of the plant were inspected spectrophotometrically and their antioxidant activities were accomplished by total antioxidant capacity (TAC) method and then compared with standards such as butylated hydroxyanisole and butylated hydroxytoluene. The results indicated that the TP content of aerial parts of $N$. officinale was 8.03$9.35 \mathrm{mgGA} / \mathrm{Eg}$ in vegetative period and 6.5-7.65 $\mathrm{mgGA} / \mathrm{Eg}$ in generative period. In addition, TF contents were $26.5-31.11 \mathrm{mgQu} / \mathrm{Eg}$ in vegetative period and 36.89-42.65 $\mathrm{mgQu} / \mathrm{Eg}$ in generative period. The highest secondary metabolites contents of TP were present in vegetative period. Half maximal inhibitory concentration (IC50) contents in aerial parts of the plant were $932-1494 \mu \mathrm{g} / \mathrm{mL}$ in TAC method. The chief antioxidant activity and radical scavenging effects were observed in vegetative period with the lowest IC50, 932-1227.5 $\mu \mathrm{g} / \mathrm{mL}$, whereas generative period with the highest amount of IC50 had the weakest antioxidant activity. Tevfikozen et al. [55] revealed that aqueous and ethanolic extract of watercress are novel antioxidants against lipid peroxidation in linoleic acid, liver, brain, and kidney homogenate model systems. It was proved that watercress has antioxidant effects to reduce cellular lipid peroxidation, superoxide anion, and free radical scavenging activities. Intake of watercress in daily diet declined DNA damage and increased blood antioxidant status in healthy adults. Alfredo et al. [56] reported phytochemical and antioxidant potential of fresh baby leaves of watercress. Two major classes of healthier secondary plant metabolites phenolics and glucosinolates were identified. The major phenolics determined were chlorogenic acid, quercetin-3-0-rutinoside, dicaffeoyltartaric acid, and isorhamnetin. The glucosinolates were comprised exclusively of gluconasturtiin, the precursor of the anticarcinogenic and antimicrobial compound 2-phenylethyl isothiocyanate. The extracts of organic young baby-leaf watercress exhibited great antioxidant activity due to the presence of caffeic acid, quercetin-3-0-rutinoside, isorhamnetin, and gluconasturtiin. Bahramikia et al. [57] studied the antioxidant efficacy of $N$. officinale extracts using various in vitro assay systems and reported that the watercress extract exhibited phenolic and flavonoid contents of $96.2 \mathrm{mg}$ gallic acid equivalents/g dried extract and $63.2 \mathrm{mg}$ catechin equivalents/g dried extract, respectively. The extract possessed potent antioxidant potential that was mediated through direct trapping of free radicals, reducing power, as well as through metal chelating.

\section{ANTIHYPERLIPIDEMIC ACTIVITY}

Mousa et al. [47] reported that hydroalcoholic extract of watercress demonstrated significant decrease in serum total cholesterol and low-density lipoprotein (LDL) cholesterol levels on repeated oral administration in streptozotocin (STZ) diabetic rats. The study claimed that treatment with watercress extract at a dose of $200 \mathrm{mg} / \mathrm{kg}$ for 4 weeks significantly declined the levels of total cholesterol and LDL cholesterol compared to diabetic animals. The mechanism by which watercress exerts lipid-lowering activity could be due to depression in cholesterol absorption from the intestine, its binding with bile acids within the intestine and increasing bile acids excretion, and a decrease of cholesterol biosynthesis also enhanced uptake of LDL by increasing LDL receptors. The study represented that the plant flavonoids, phenolic compounds, and glycosides were responsible for hypocholesterolemia and hypolipidemic activities.

\section{ANTIDIABETIC ACTIVITY}

Hoseini et al. [58] reported antidiabetic potential of watercress plant employing STZ-induced diabetes in rats. The author claimed that aqueous, ethyl acetate, and methanolic extract of plant exhibited antidiabetic potential. The methanolic extract of the plant at a dose of 800 and $1000 \mathrm{mg} / \mathrm{kg}$ significantly reduced the blood glucose level to $132.5 \mathrm{mg} / \mathrm{dL}$ and $125.5 \mathrm{mg} / \mathrm{dL}$, respectively, as compared to diabetic control rats $275.7 \mathrm{mg} / \mathrm{dL}$ after 1 week of treatment. The ethyl acetate extract at a dose of $100 \mathrm{mg} / \mathrm{kg}$ significantly reduced the blood glucose level to $142.5 \mathrm{mg} / \mathrm{dL}$ as compared to control rats group $266.5 \mathrm{mg} / \mathrm{dL}$ and rats treated with standard drug glibenclamide represented blood glucose level of $255.2 \mathrm{mg} / \mathrm{dL}$ at a dose of $100 \mathrm{mg} / \mathrm{kg}$ for 2 months. The hypoglycemic potential can be due to stimulation of Langerhans islets. Consumption of watercress leaves impaired the obstacles of hyperglycemia and dyslipidemia associated with diabetes. It also upturns serum glucose levels. Engelen et al. [59] reported that watercress comprised glucosinolates (gluconasturtiin), which has been traditionally used for the treatment of diabetes, an endocrinal chronic disease caused by altered carbohydrate metabolism and characterized by elevated serum glucose levels. 


\section{ANTIBACTERIAL ACTIVITY}

Gerard et al. [60] reported antibacterial activity of watercress against various bacterial strains. The results revealed that aqueous and ethanolic extract possessed significant antibacterial activity against Staphylococcus aureus, Bacillus subtilis, Escherichia coli, and Pseudomonas aeruginosa. The phytoconstituents accountable for the antibacterial activity are tannins, flavonoids, terpenoids, and various glycosides, which aided in the treatment of numerous skin bacterial infections. Sadeghi et al. [61] synthesized silver nanoparticles (Ag-NPs) using leaves aqueous extract of $N$. officinale $\mathrm{R}$. Br. (NO) and estimated its antibacterial activity against the growth of Gram-positive (S. aureus) using standard error mean (SEM). The inhibition was observed in the Ag-NPs against $S$. aureus. The results of SEM revealed that most of S. aureus strain was impaired and extensively diminished by the addition of Ag-NPs. The results certified that the $N$. officinale is an excellent eco-friendly and non-toxic source for the synthesis of Ag-NPs. Zafar et al. [32] demonstrated antibacterial potential of methanolic extract of $N$. officinale against E. coli, Salmonella typhi, Streptococcus pneumoniae, and Proteus vulgaris. Khan et al. [62] also reported antibacterial activity of watercress.

\section{ANTI-INFLAMMATORY ACTIVITY}

Sadeghi et al. [63] demonstrated the anti-inflammatory potential of the hydroalcoholic extract from the aerial parts of $N$. officinale in different animal models of inflammation, that is, carrageenan-induced paw edema in rats, formaldehyde-induced paw edema in rat, and120 -tetradecanoylphorobol-13 acetate-evoked ear edema in mice. The results expressed that oral administration of $N$. officinale at $(250,500$, and $750 \mathrm{mg} / \mathrm{kg}$ ) noticeably inhibited carrageenan-induced paw edema over a period of $4 \mathrm{~h}$, and anti-inflammatory activities of the extract at 500 and $750 \mathrm{mg} / \mathrm{kg}$ were significantly compared with indomethacin $(10 \mathrm{mg} / \mathrm{kg})$. The extract at a dose of $500 \mathrm{mg} / \mathrm{kg}$ significantly reduced the development of formalin-induced paw edema in rats at 1,2, 3, 4, and $24 \mathrm{~h}$ after injection of formalin as compared with indomethacin at 10 $\mathrm{mg} / \mathrm{kg}$ dose. The extract at $5 \mathrm{mg} /$ ear represented noticeable inhibitory effect in comparison with control group in TPA-induced rat ear edema. Molaei et al. [64] determined the watercress extract on red blood cells (RBC) membrane stability as an anti-inflammatory agent in female rats. The results indicated that 4 and $6 \mathrm{mg} / \mathrm{kg} /$ body weight of watercress extract has anti-inflammatory effect on RBC in female rodents.

\section{ANTIHYPERTENSIVE ACTIVITY}

Catty et al. [65] reported that watercress (N. officinale R. Br.) exhibited angiotensin-converting enzyme inhibitory activity in ethanolic extract with IC50 value $19.05 \mu \mathrm{g} / \mathrm{mL}$ and the maximum IC50 value of ethyl acetate was $2.303 \mu \mathrm{g} / \mathrm{mL}$. The author reported that n-butanol fraction had the highest TP content with $15.798 \mathrm{mg} \mathrm{GAE} / \mathrm{g}$ of extract, while maximum TF content was collected in ethyl acetate fraction with $82.847 \mathrm{mg} \mathrm{QE} / \mathrm{g}$ of the extract.

\section{HEPATOPROTECTIVE ACTIVITY}

Ebadollahi et al. [66] extracted total parts of plant with alcohol-water and then sequentially fractioned using petroleum ether, $n$-butanol, and water, respectively. The results revealed that total extract, alcohol-water $(175 \mathrm{mg} / \mathrm{kg})$, and aqueous extract $(50 \mathrm{mg} / \mathrm{kg})$ of the whole part of $N$. officinale significantly prevented acetaminophen-induced rise in serum levels of aspartate aminotransferase, alanine aminotransferase, and lactate dehydrogenase. The histopathological changes of liver induced by acetaminophen were considerably reversed following treatment by aqueous and total extract of $N$. officinale. Karami et al. [67] investigated the protective activity of the methanolic extract of $N$. officinale against gamma-radiation-induced hepatotoxicity along with histopathological changes. The results revealed that pre-treatment with $100 \mathrm{mg} / \mathrm{kg}$ body weight of plant extract per day for 15 days and $2 \mathrm{~h}$ before $\gamma$-radiation significantly lowered incidence of inflammation (portal and periportal inflammation). Furthermore, liver cells necrosis, edema, and congestion were slightly reduced. The TP and TF contents of the extract were $11.3 \pm 0.4 \mathrm{mg}$ gallic acid equivalents and $9.4 \pm 0.7 \mathrm{mg}$ quercetin equivalents per gram of dried extract.

\section{ANTIULCER ACTIVITY}

Bettega et al. [68] reported the efficacy of ethanolic extract of $N$. officinale as an adjuvant on the healing of traumatic ulcers on rat tongue dorsum. It was observed that the solution of $N$. officinale promoted an increase in fibroblasts with a consequent lift of the deposition of collagen before the $7^{\text {th }}$ day of post-ulceration, and it remained constant throughout the experimental interval. Still, the phytochemical accelerated the substitution rate of immature collagen (rich in fibers, Type III thin) to mature collagen (rich in fiber, Type I thick).

\section{ANTITUBERCULAR ACTIVITY}

Rodrigo et al. [69] reported that chloroform extract of $N$. officinale demonstrated antitubercular potential. The antimycobacterial properties of $N$. officinale could be attributed in part to the presence of E-phytol (minimum inhibitory concentration $[\mathrm{MIC}]=12.5 \mu \mathrm{g} / \mathrm{ml}$ ) and palmitic acid (MIC $=50 \mu \mathrm{g} / \mathrm{ml}$ ) against Mycobacterium tuberculosis H37Rv. Corona et al. [22] reported $N$. officinale as most potent (MIC $\leq 100 \mu \mathrm{g} / \mathrm{ml}$ ) against the four monoresistant variants tested against tuberculosis.

\section{ANTICANCER ACTIVITY}

Boyd et al. [70] demonstrated that watercress extract protects colon cancer HT29 cells from oxidative DNA damage induced by various genotoxins, 4-hydroxynonenal, hydrogen peroxide, and fecal water. Hecht et al. [71] reported that the consumption of watercress, 56.8 $\mathrm{g}$ for each 3 days inhibited the metabolic activities of a key tobacco carcinogen NNK in some smokers. Furthermore, consumption of $85 \mathrm{~g}$ of raw watercress once a day for 8 weeks decreased several measures of DNA damage in lymphocytes, a cancer biomarker and increased plasma levels of the antioxidant, $\beta$-carotene, and lutein. Rose et al. [72] demonstrated that watercress extract, although more specifically the non-volatile 7-methylsulfinyl heptyl isothiocyanate component, reduced MMP9 activity in the human breast cancer MDAMB-231 cell line. Moradi et al. [73] examined the antioxidant properties and the phenolic, flavonoid, and anthocyanin contents of hydroalcoholic extract of watercress extract and its effect on the growth of cancerous Hela cells and fibroblasts. The phenolic and flavonoid contents of the extract were determined through a spectrophotometric method. Antiradical activity of the extract was examined using the RSA test of 2, 2-diphenyl-1 picrylhydrazyl. The extract was applied on cancerous Hela cell line and fibroblasts at concentrations varying from 0.625 to $2 \mathrm{mg} / \mathrm{mL}$ and cell mortality rates were examined after 24,48 , and $72 \mathrm{~h}$ incubation using the MTT test. The survival rate of the cancerous Hela cells decreased with time and increasing concentrations of watercress extract. IC50 values after 24,48 , and $72 \mathrm{~h}$ were 373,349 , and $333 \mu \mathrm{g} / \mathrm{mL}$, respectively. Fallah and Ebrahimi [74] reported the anticancer activity of hydroalcoholic extract of watercress plant on MDA-MB-231 breast cancer cells at different concentrations $(0-2 \mathrm{mg} / \mathrm{mL})$ employing MTT assay. Bashir et al. [75] reported that watercress juice significantly elevated Uridine 5'-diphospho-glucuronosyltransferase (UDP-glucuronosyltransferase, UGT) enzyme activity in human-derived hepatoma cell line (HepG2) and Lhoste et al. [76] reported that the juice from watercress significantly elevated the activities of ethoxyresorufin-0-deethylase and NAD (P) $\mathrm{H}$-quinone reductase in HepG2 cells.

\section{ANTIFUNGAL ACTIVITY}

Jafarnikan et al. [77] studied antifungal potential of alcoholic watercress extract on the growth of Fusarium solani, the causal agent of potato dry rot. The research was carried out employing the paper disc diffusion method and the assessment was done by measuring the growth inhibition zone of the fungus on potato dextrose agar medium. The different concentrations $(300,400,500$, and $600 \mathrm{mg} / \mathrm{mL})$ of watercress extract were prepared and assessed for antifungal activity. The results represented that the highest zone of inhibition was accomplished at 
$600 \mathrm{mg} / \mathrm{mL}$. The author recommended the use of watercress plant extract in manufacturing natural fungicidal compounds.

\section{NEMATOCIDAL ACTIVITY}

Zahradnikova et al. [78] evaluated the effect of watercress eluate and juice on tomato plants inoculated with the northern root-knot nematode (Meloidogyne hapla). It was discovered that the treatment of plants with solutions derived from watercress resulted in significant increased yield of fruit. The highest yield increment (by 96-165\%) was estimated in the variant with the highest concentration of watercress extracts (macerate $+200 \mathrm{~mL}$ of juice). While estimating the occupancy of nematodes on roots of tomato plants, the presence of pathogens was found out $0 \%$ in all treated variants. The treatment with this phytosolution corroborated not only a nematocidic effect of watercress but also its positive influence on the yield and level of Vitamin C in dependence on increasing concentrations of the effective agent.

\section{NEPHROPROTECTIVE ACTIVITY}

Karami et al. [79] inspected the potential of hydroalcoholic extract of $N$. officinale (NOE) and Vitamin E against vancomycin (VCM)-induced nephrotoxicity against adult Wistar male rats. VCM significantly escalated serum creatinine and urea levels, MDA levels, kidney weight $/ 100 \mathrm{mg}$ weight of body, as well as reduced creatinine clearance. NOE $(250$ and $500 \mathrm{mg} / \mathrm{kg})$ and Vitamin E $(500 \mathrm{mg} / \mathrm{kg})$ pretreatment considerably alleviated all of these changes when compared with VCM treated alone. Histological examination of VCM-treated group showed a marked renal injury with tubular epithelial cell desquamation, swelling, and tubular dilatation. These changes were mitigated with NOE and Vitamin E

\section{ANTITUMOR ACTIVITY}

Debora Aparecida de Souza et al. [80] investigated the effects of daily intake of an aqueous solution of watercress on the growth of the experimental Ehrlich tumor (EET). The study showed that, from the $2^{\text {nd }}$ week after tumor inoculation, a reduction in tumor growth was observed in the animals receiving daily dose of aqueous watercress solution in relation to the animals of the control group. The reduction in footpad thickness was significant from the day 10 and was maintained until the end of the experiment, the histopathological examination of footpad of animals treated with aqueous solution of watercress represented reduced necrotic areas.

\section{IMMUNOMODULATORY ACTIVITY}

Asadi et al. [81] investigated the immunomodulatory effects of watercress extract on immunological and hematological parameters of rainbow trout (Oncorhynchus mykiss). Fish were fed for 21 days with diet supplemented with $0.1 \%$ and $1 \%$ of watercress extract per $1 \mathrm{~kg}$ food and with a normal diet as control. Hematological parameters such as RBC and white blood cells, hematocrit, hemoglobin (Hb), RBC index like mean corpuscular volume, mean corpuscular hemoglobin (MCH), and $\mathrm{MCH}$ concentration (MCHC) as well as immunological parameters such as peroxidase, lysozyme and complement activities, total protein, albumin, and globulin levels were measured after 21 days of watercress extract treatment. The results indicated that oral administration of $1 \%$ watercress extract in fish may enhance some hematological and immunological parameters including $\mathrm{Hb}$ and $\mathrm{MCHC}$, lysozyme and complement activities, total protein, and globulin levels, compared to the controls after 21 days of experimental period. On the basis of these results, author concluded that oral administration of watercress extract may be useful to improve fish's immune system.

\section{PSYCHOACTIVE ACTIVITY}

Otsuka et al. [82] performed a literature search of the available publications on medicinal plants. The purpose of the current study was to select plants with psychoactive effects described in a Brazilian literary work written by Pio Correa in 1926. The plant species were researched through a database search, and all the obtained information were compiled into a new database to analyze possible correlations between the chemical compounds and the psychoactive categories. of 813 plants searched in the literary work, 104 presented chemical data in the scientific periodicals consulted. 75 of them belong to the stimulant category, in this research, it was mentioned that whole part of $N$. officinale exhibited stimulant potential due to the presence of glucosinolates and carotenoids as vital phytoconstituents.

\section{BURN HEALING ACTIVITY}

Zinadah [83] reported the healing potential of watercress oil on thermal and chemical burn injuries in rabbits. Watercress oil was applied to the experimental burns induced chemically and by direct heat, to investigate its effect on epithelization of the hair follicles, and it was observed that animals in treated groups restored the normal architecture more rapidly with significant reduction in closure time of burn.

\section{ANTIRHEUMATIC}

Panda et al. [84] reported the traditional use of N. officinale (watercress) seeds in the treatment of rheumatism by the residents of Odisha.

\section{CONCLUSION}

$N$. officinale (watercress) plant is now explored as a prominent herb that can be used in medicinal field due to its substantial usage. Conventionally, the plant has been used to cure multiple diseases that are indicated in the manuscript. The present review hence divulges the full therapeutic potential of this plant and invites further researchers to provide a platform to establish it as a standard drug in the pharmaceutical industry.

\section{AUTHORS' CONTRIBUTION}

Hazar Hisham and Doha Mohamed were responsible for downloading the relevant publications from SciFinder, PubMed, ScienceDirect, and Google Scholar database and preparing notes for the manuscript. Sachin Chaudhary was responsible for designing the manuscript and assisted in drafting the notes for the manuscript.

\section{CONFLICTS OF INTEREST}

The authors declare that they have no conflicts of interest.

\section{REFERENCES}

1. Dragland S, Senoo H, Wake K, Holte K, Blomhoff R. Several culinary and medicinal herbs are important sources of dietary antioxidants. J Nutr 2003;133:1286-90.

2. Prakash P, Gupta N. Therapeutic uses of Ocimum sanctum Linn (Tulsi) with a note on eugenol and its pharmacological actions: A review. Indian J Physiol Pharm 2005;49:125-31.

3. Dangol DR. Traditional uses of plants of common land habitats in Western Chitwan, Nepal. J Inst Agric Anim Sci 2008;29:71-8.

4. Cowan MM. Plant products as antimicrobial agents. Clin Microbiol Rev 1999;12:564-82.

5. Getahun SM, Chung FL. Conversion of glucosinolates to isothiocynathes in humans after ingestion of cooked watercress. Cancer Epidemiol Biomarkers Prev 1999;8:447-451.

6. Kumar VS, Navaratnam V. Neem (Azadirachtaindica): Prehistory to contemporary medicinal uses to humankind. Asian Pac J Trop Biomed 2013;3:505-14.

7. Vishwakarma AP, Vishwe A, Sahu P, Chaurasiya A. Magical remedies of Terminalia arjuna (ROXB.). Int J Pharm Arch 2013;2:189-201.

8. Rudra S, Kalra A, Kumar A, Kumar A, Joe W. Utilization of alternative systems of medicine as health care services in India: Evidence on AYUSH care from NSS 2014. PLoS One 2017;12:1-20.

9. Ravishankar B, Shukla VJ. Indian systems of medicine: A brief profile. Afr J Tradit Complement Altern Med 2007;4:319-37.

10. Shakya AK. Medicinal plants: Future source of new drugs. Int J Herbal Med 2016;4:59-64

11. Shu YZ. Recent natural products based drug development: 
A pharmaceutical industry perspective. J Nat Prod 1998;61:1053-71.

12. Clark AM. Natural products as a resource for new drugs. Pharm Res 1996;13:1133-44.

13. Jhansi T. A review on medicinal plants. J Med Org Chem 2016;3:157-65.

14. Kia FJ, Lorigooini Z, Khoei HA. Medicinal plants: Past history and future perspective. J Herbmed Pharm 2018;7:1-7.

15. Rates SMK. Plants as source of drugs. Toxicon 2001;39:603-13.

16. Hamburger M, Hostettmann K. Bioactivity in plants: The link between phytochemistry and medicine. Phytochemistry 1991;30:3864-74.

17. Howard AH, Lyon AG. Nasturtium officinale R. Br. (Rorippa Nasturtium aquaticum (L.) Hayek). J Ecol 1952;40:228-45.

18. Verhoeven DT, Goldbohm RA, van Poppel G, Verhagen H, van den Brandt PA. Epidemiological studies on brassica vegetables and cancer risk. Cancer Epidemiol Biomarkers Prev 1996;5:733-48.

19. Manchali S, Murthy KN, Patil BS. Crucial facts about health benefits of popular cruciferous vegetables. J Funct Foods 2012;4:94-106.

20. Wagner AE, Terschluesen AM, Rimbach G. Health promoting effects of brassica-derived phytochemicals: From chemopreventive and antiinflammatory activities to epigenetic regulation. Oxid Med Cell Longev 2013;2013:964539.

21. Manton I. The cytological history of Watercress (Nasturtium officinale R. Br.). Z Indukt Abstamm Vererbungsl 1935;69:132-57.

22. Camacho-Corona Mdel R, Ramírez-Cabrera MA, Santiago OG, GarzaGonzález E, Palacios Ide P, Luna-Herrera J, et al. Activity against drug resistant-tuberculosis strains of plants used in Mexican traditional medicine to treat tuberculosis and other respiratory diseases. Phytother Res 2008;22:82-5.

23. Jafari S, Hassandokht M. Evaluation of some Iranian watercress (Nasturtium officinale L.) populations using agro-morphological traits. Int J For Soil Erosion 2012;2:119-23.

24. Albermani SS, Albermani A, Altameme HJ. Systematic study of the genus nasturtium R. Br (Brassicaceae) in Iraq. J Chem Pharm Sci 2017; 10:352-8.

25. Bleeker W, Huthmann M, Hurka H. Evolution of hybrid taxa in nasturtium R. Br. (Brassicaceae). Folia Geobot 1999;34:421-33.

26. Franzke A, Lysak MA, Al-Shehbaz IA, Koch MA, Mummenhoff K. Cabbage family affairs: The evolutionary history of Brassicaceae. Trends Plant Sci 2011;16:108-16.

27. Goncalves EM, Cruz RM, Abreu M, Brandao TR, Silva CL. Biochemical and colour changes of watercress (Nasturtium officinale $\mathrm{R}$. Br.) during freezing and frozen storage. J Food Eng 2009;93:32-9.

28. Khalik KA. Morphological studies on trichomes of Brassicaceae in Egypt and taxonomic significance. Acta Bot Croat 2005;64:57-73.

29. Bleasdale JK. The flowering and growth of watercress (Nasturtium officinale R. Br.). J Hortic Sci 1964;39:277-83.

30. Cumbus IP, Robinson LW. The function of root systems in mineral nutrition of watercress (Rorippa Nasturtium aquaticum (L) Hayek). Plant Soil 1977;47:395-406.

31. Voutsina N, Payne AC, Clarkson GJ, Rothwell SD, Chapman MA, Taylor G. Characterization of watercress (Nasturtium officinale R. Br.; Brassicaceae) transcriptome using RNASeq and identification of candidate genes for important phytonutrient traits linked to human health. BMC Genomics 2016;17:1-15.

32. Zafar R, Zahoor M, Shah AB, Majid F. Determination of antioxidant and antibacterial activities, total phenolic, polyphenol and pigment contents in Nasturtium officinale. Pharm Online 2017;1:11-8

33. Boligon AA, Janovik V, Pivetta CR, Pereira, Da Rocha JB, Athayde ML. HPLC analysis of polyphenolic compounds and antioxidant activity in Nasturtium officinale. Int J Food Prop 2013;16:61-9.

34. Meriem T, Soumia K, Fairouz S. Oral acute toxicity and antioxidant activity of the watercress ethanolic extract: Nasturtium officinale $\mathrm{R} . \mathrm{Br}$ (Bracicasseae). Res Rev: J Bot Sci 2017;6:14-8.

35. Al-Shehbaz IA, Rollins RC. A reconsideration of Cardamine curvisiliqua and C. gambelliias species of Rorippa (Cruciferae). J Arnold Arbor 1988;69:65-71.

36. Palanisamy UR, Mcavoy RJ. Watercress; A salad crop with chemo preventive potential. Horttechnology 2001;11:622-6.

37. Goda Y, Hoshino K, Akiyama H, Ishikawa T, Abe Y, Nakamura T, et al. Constituents in watercress, inhibitors of histamine release from RBL-2H3 cells induced by antigen stimulation. Biol Pharm Bull 1999;22:1319-26.

38. Faizy H, Al-Zubaydi S. Antioxidant assay (MTT) of watercress (Nasturtium officinale) bioactive compounds in Duhok/Kurdistan region of Iraq. Int J Chem Environ Bio Sci 2017;5:50-7.

39. Keser G, Saygideger S. Effects of lead on the activities of antioxidant enzymes in watercress, Nasturtium officinale R. Br. Biol Trace Elem Res 2010;137:235-43.
40. Gill CI, Haldar S, Boyd LA, Bennett R, Whiteford J, Butler M, et al. Watercress supplementation in diet reduces lymphocyte DNA damage and alters blood antioxidant status in healthy adults. Am J Clin Nutr 2007;85:504-10

41. Casanova NA, Wagner ML, Nigro MM, Carballo MA. Effect of watercress on induced DNA damage, DNA repair and P-glycoprotein activity in human lymphocytes. J Basic App Chem 2014;25:53-60.

42. Namavari R, Ardakani MR, Torabi S. Morphophysiological responses of watercress (Nasturtium officinale) super food to organic media. An Int J 2015;7:522-5.

43. Haro G, Iksen I, Rumanti RM, Marbun N, Sari RP, Gultom RP. Evaluation of antioxidant activity and minerals value from watercress (Nasturtium officinale R. Br.). Rasayan J Chem 2018;11:232-7.

44. Mojab F, Kamalinejad M, Ghaderi N, Vahidipour HR. Phytochemical screening of some species of Iranian plants. Iran J Pharm Res 2003;2:77-82

45. Casanova NA, Wagner ML, Lopez NM, Carballo MA. Effect of watercress on induced DNA damage, DNA repair and P-glycoprotein activity in human lymphocytes. J Basic Appl Genet 2014;25:53-60.

46. Hayes JD, Kelleher MO, Eggleston IM. The cancer chemopreventive actions of phytochemicals derived from glucosionolates. Eur J Nutr 2008;47:73-88.

47. Hadjzadeh MA, Rajaei Z, Moradi R, Ghorbani A. Effects of hydroalcoholic extract of watercress (Nasturtium officinal) leaves on serum glucose and lipid levels in diabetic rats. Indian J Physiol Pharm 2015;59:223-30.

48. Pinela J, Prieto MA, Barros L, Carvalho AM, Oliveira MB, Saraiva JA, et al. Cold extraction of phenolic compounds from watercress by high hydrostatic pressure: Process modelling and optimization. Sep Purif Technol 2018;192:501-12.

49. Afsharypuor S, Salehi M. Volatile constituents of leaves and stems of Nasturtium officinale R. Br. J Essent Oil Res 2008;20:517-8.

50. Fernandez JA, Ninirola D, Ochoa J, Orsini F, Pennisi G, Gianquinto G, et al. Root adaptation and ion selectivity affects the nutritional value of salt-stressed hydroponically grown baby-leaf Nasturtium officinale and Lactuca sativa. Agric Food Sci 2016;25:230-9.

51. Szczykutowicz MK, Szopa A, Ekiert H. Chmeical composition, tradition and professional use in medicine, application in environment protection, position in food and cosmetics industries, and biotechnological studies of Nasturtium officinale (watercress)-a review. Fitoterapia 2018;129:283-92.

52. Zargari F, Ghorbanihaghjo A, Babaei H. Protective effects of hydroalcoholic extract of Nasturtium officinale on rat blood cells exposed to arsenic. Iran J Toxicol 2015;9:1331-5.

53. Zeb A. Phenolic profile and antioxidant potential of wild watercress (Nasturtium officinale L.). Springerplus 2015;4:714.

54. Mazandarani M, Azar M, Parastoo ZM. Evaluation of phytochemical and antioxidant activities from different parts of Nasturtium officinale R. Br. In Mazandaran. Iran J Plant Physiol 2012;3:659-64.

55. Ozen T. Investigation of antioxidant properties of Nasturtium officinale (watercress) leaf extracts. Acta Pol Pharm 2009;66:187-93.

56. Aires A, Carvalho R, Rosa EA, Saavedra MJ. Phytochemical characterization and antioxidant properties of baby-leaf watercress produced under organic production system. CyTA-J Food 2013;11:343-51

57. Bahramikia S, Yazdanparast R. Antioxidant efficacy of Nasturtium officinale extracts using various in vitro assay systems. J Acupunct Meridian Stud 2010;3:283-90.

58. Hoseini HF, Gohari AR, Saeidnia S, Majd NS, Hadjiakhoondi A. The effect of Nasturtium officinale on blood glucose level in diabetic rats. Pharm Online 2009;3:866-71.

59. Engelen-Eigles G, Holden G, Cohen JD, Gardner G. The effect of temperature, photoperiod, and light quality on gluconasturtiin concentration in watercress (Nasturtium officinale R. Br.). J Agric Food Chem 2006;54:328-34

60. Penecilla GL, Magno CP. Antibacterial activity of extracts of twelve common medicinal plants from the Philippines. J Med Plants Res 2011;5:3975-81

61. Sadeghi B. Synthesis of silver nanoparticles using leaves aqueous extract of Nasturtium officinale (NO) and its antibacterial activity. Int J Mol Clin Microbiol 2014;2:428-34

62. Khan H, Jan SA, Javed M, Shaheen R, Khan Z, Ahmed A, et al. Nutritional composition, antioxidant and antimicrobial activities of selected wild edible plants. J Food Biochem 2015;40:61-70.

63. Sadeghi H, Mostafazadeh M, Sadeghi H, Naderian M, Barmak MJ, Talebianpoor MS, et al. In vivo anti-inflammatory properties of aerial parts of Nasturtium officinale. Pharm Biol 2014;52:169-74 
64. Molaei S, Ahmadi R, Syiavashi M, Alaee Z. The anti-inflammatory effects of watercress extract on RBCs in female rats. Int Conf Food Biol Med Sci 2014;2014:28-9.

65. Yaricsha CA, Katrin R. ACE inhibitory activity, total phenolic and flavonoid content of watercress (Nasturtium officinale $\mathrm{R}$. Br.) extract. Pharm J 2017;9:249-51.

66. Natanzi AR, Ghahremani MH, Esfehani HR, Minaei MB, Nazarian H, Sabzevari O. Evaluation of anti-hepatotoxic effect of Watercress extract and its fractions in rats. Int J Pharm 2010;6:896-902.

67. Karami M, Mostafazadeh M, Sadeghi H, Sadeghi H, Mehraban F, Kokhdan EP, et al. Nephroprotective effect of Nasturtium officinale (watercress) ethanol extract and Vitamin E on vancomycin-induced nephrotoxicity in rats. Jundishapur J Nat Pharm Prod 2018;13:1-8.

68. Bettega PV, Johann AC, Alanis LR, Bazei IF, Miguel OG, Kocler CC, et al. Experimental confirmation of the utility of Nasturtium officinale used empirically as mouth lesion repairing promotor. J Cli Exp Pharm 2016;6:1-6.

69. Lazaro RQ, Eunice A, Zuniga F, Garcia A, Gonzalez EG, Alvarez L, et al. Antimycobacterial compounds from Nasturtium officinale. Afr J Tradit Complement Altern Med 2016;13:31-4.

70. Boyd LA, McCann MJ, Hashim Y, Bennett RN, Gill CI, Rowland IR, et al. Assessment of the anti-genotoxic, anti-proliferative, and antimetastatic potential of crude watercress extract in human colon cancer cells. Nutr Cancer 2006;55:232-41.

71. Hecht SS, Chung FL, Richie JP Jr. Akerkar SA, Borukhova A, Skowronski L, et al. Effects of watercress consumption on metabolism of a tobacco-specific lung carcinogen in smokers. Cancer Epidemiol Biomarkers Prev 1995;4:877-84.

72. Rose P, Huang Q, Ong CN, Whiteman M. Broccoli and watercress suppress matrix metalloproteinase- 9 activity and invasiveness of human MDA-MB-231 breast cancer cells. Toxicol Appl Pharmacol 2005;209:105-13.

73. Moradi R, Ebrahimi S, Taravati A, Asrardel F, Khorasani HR, Aghajanpour M, et al. Cytotoxic effects of the hydroalcoholic extract of Rorippa Nasturtium aquaticum on hela cell line. Int Bio Biomed J 2017;3:73-9.
74. Fallah N, Ebrahimi S. The anti-cancer effect of watercress (Rorripa Nasturtium aquaticum) extract on breast cancer cells. Zahedan J Res Med Sci 2016;18:1-7.

75. Bashir MK, Ismail S, Lam CK, Chua JK, Hussain AH. The in vitro and ex vivo effect of Phyllanthus niruri methanol extract on hepatic UDP-glucuronyl transferase enzyme activity in STZ-induced diabetic spraguedawley rats. Int J Pharm Pharm Sci 2015;7:105-9.

76. Lhoste EF, Gloux K, Waziers ID, Garrido S, Lory S, Philippe C, et al. The activities of several detoxication enzymes are differentially induced by juices of garden cress, watercress and mustard in human HepG2 cells. Chem Biol Interact 2004;150:211-9.

77. Nikan J, Khavari H. In vitro anti-fungal activity of watercress (Nasturtium officinale) extract against Fusarium solani, the causal agent of potato dry rot. J Herb Drugs 2014;5:19-24.

78. Zahradnikova H, Petrikova K. Nematocid effects of watercress (Nasturtium officinale R. BR.). Acta Univ Agric Silvic Mendel Brun 2013;61:233-6.

79. Karami M, Mostafazadeh M, Sadeghi H, Sadeghi H, Mehraban F, Kokhdan EP, et al. Nephroprotective effect of Nasturtium officinale (watercress) ethanol extract and Vitamin E on vancomycin-induced nephrotoxicity in rats. Jundishapur J Nat Pharm Prod 2018;13:1-8.

80. De souza DA, Costa PM, Ribeiro RI, Vidigal PV, Pinto FC. Daily intake of watercress causes inhibition of experimental Ehrlich tumor growth. J Bras Patol Med Lab 2016;52:393-9.

81. Asadi MS, Mirvaghefei AR, Nematollahi MA, Banaee M, Ahmadi K. Effects of watercress (Nasturtium nasturtium) extract on selected immunological parameters of rainbow trout (Oncorhynchus mykiss). Open Vet J 2012;2:32-9.

82. Otsuka RD, Lago JH, Rossi L, Galduróz JC, Rodrigues E. Psychoactive plants described in a Brazilian literary work and their chemical compounds. Cent Nerv Syst Agents Med Chem 2010;10:218-37.

83. Zinadah OA. Effects of watercress oil on the thermal and chemical burn injuries in rabbits. Med Sci 2008;15:3-17.

84. Panda SS, Sahu AC, Dhal NK. Documentation of tribal claims for rheumatism in Odisha, India. Int J Pharm Pharm Sci 2015;7:379-84. 